\title{
ANALISIS FAKTOR-FAKTOR YANG MEMPENGARUHI EFEKTIVITAS ORGANISASI DI BPS KABUPATEN/KOTA SE-NUSA TENGGARA BARAT
}

\author{
Oleh: \\ Chairul Fatikhin Putra ${ }^{1}$ \\ Agusdin $^{2}$ \\ Hermanto $^{3}$
}

\begin{abstract}
This research was aimed at determining the effect and level of trend of effect of factors affecting organizational effectiveness consisting of leadership, organizational structure, human resource capability, and motivation on the effectiveness of organization in district offices of BPS in West Nusa Tenggara. This research was quantitative descriptive study with 128 respondents. The data were collected through close questionnaires. The data were analyzed using logical regression analysis with SPSS 20.0. The research showed that: (1) leadership had positive but not significant effect on organizational effectiveness, (2) organizational structure had positive and significant effect on organizational effectiveness, (3) human resource capability had positive and significant effect on organizational effectiveness, (4) motivation had positive and significant effect on organizational effectiveness, (5) good organizational structure, good human resource capability, and high motivation had the trend of effect on how good organizational effectiveness subsequently as 14.22, 10.47, and 9.96 times comparing to the other side. This research recommended that: (1) stakeholders need to improved the quality of organizational structure, human resource capability, and motivation for better organizational effectiveness, (2) further research need to considered other independent variables in the analysis.
\end{abstract}

Keywords: organizational effectiveness, leadership, organizational structure, human resource capability, motivation

\section{Pendahuluan}

Dalam era reformasi birokrasi ini, tentunya semua instansi pemerintah tak terkecuali BPS wajib melakukan perubahan mewujudkan birokrasi yang lebih baik. Banyak tantangan yang harus dihadapi baik dari segi internal maupun eksternal organisasinya. Masyarakat dan instansi pemerintah lainnya terutama konsumen data sangat menuntut data yang berkualitas, cepat, dan terbarukan. Oleh karena itu, BPS dituntut dapat lebih proaktif dalam meningkatkan efektivitas organisasinya. Terlebih lagi untuk terpacu dan berlomba-lomba menciptakan efektivitas organisasi dengan lebih baik demi memuaskan masyarakat dan tercapainya tujuan organisasi.

Menurut Yatchman dan Seastore dalam Steers (1985), efektivitas organisasi adalah kapasitas suatu organisasi untuk memperoleh dan memanfaatkan sumber dayanya yang langka dan berharga secara sepadan dalam usahanya mengejar tujuan organisasi dan operasionalnya. Selain itu efektivitas organisasi dapat dinyatakan sebagai tingkat keberhasilan organisasi dalam usaha untuk mencapai tujuan atau sasaran organisasinya.

${ }^{1}$ Anggota Organisasi di Luar Kampus, Universitas Mataram 
Menurut Gibson (1984) efektivitas organisasi terdiri dari tiga pendekatan yaitu pendekatan tujuan, teori sistem, dan multiple constituency. Dari ketiga pandangan pendekatan tentang teori efektivitas organisasi tersebut, secara umum teori tujuan sering digunakan dalam pemaknaan efektivitas suatu organisasi. Hal ini dikarenakan pendekatan teori tujuan menggunakan alat ukur yang jelas terhadap efektivitas yaitu pencapaian tujuan. Jika kita kaitkan BPS berdasarkan pendekatan teori tujuan ini maka secara harfiah organisasi ini harus mengadopsi visi dan misi sebagai pedoman dan arah organisasinya. Pencapaian keberhasilan perwujudan visi dan misi BPS sebagai arah organisasi tidak akan tercapai jika organisasi tidak berjalan secara efektif dan efisien serta bersinergi.

Terlepas dari sinergitifitas organisasi, efektivitas organisasi tidak akan terwujud dengan baik apabila tidak dibarengi oleh pengelolaan yang baik pada faktor-faktor yang mempengaruhinya. Terlebih lagi jika faktor-faktor yang mempengaruhi tersebut berpengaruh signifikan, sehingga diperlukan perhatian yang lebih terkait dengan hal ini.

Dalam beberapa penelitian terakhir dapat ditemukan fakta bahwa faktor-faktor yang mempengaruhi efektivitas organisasi ini menunjukkan hasil yang berbeda dalam hal pengaruh dan tingkat keterjelasan variabel independen terhadap variabel dependennya. Beberapa contoh penelitian tersebut diantaranya adalah penelitian kualitatif mengenai kepemimpinan oleh Surbakti (2016) yang menunjukkan bahwa kepemimpinan sangat penting dalam mempengaruhi terjadinya efektivitas organisasi pada sekolah dasar di Kabupaten Deli Serdang Provinsi Sumatera Utara. Pemimpin yang mampu mendorong karyawannya untuk semangat berproduktivitas adalah pemimpin yang berhasil membawa organisasi menjadi efektif. Hal senada juga diungkapkan oleh Thahier (2016) dalam penelitian kuantitatifnya yang menunjukkan bahwa kepemimpinan berdampak signifikan dan positif terhadap efektivitas organisasi pada Dinas Kesehatan Kabupaten Wakatobi melalui dimensi variabel penentuan arah dan tujuan, membuat keputusan, motivasi karyawan, keteladanan, dan tanggung jawab terhadap kinerja organisasi. Dalam penelitian Thahier (2016) ini, lima dimensi kepemimpinan tersebut hanya dapat menjelaskan efektivitas organisasi sebesar 24,3 persen. Namun ketika variabel kepemimpinan ini digabungkan dengan variabel lainnya ternyata dapat menjelaskan efektivitas organisasi dengan persentase yang lebih besar yakni 42,1 persen seperti yang dilakukan oleh Amuniansyah (2014) dimana menggunakan variabel kepemimpinan dan spesialisasi tugas untuk melihat pengaruhnya terhadap efektivitas organisasi di Badan Kepegawaian Daerah Kabupaten Kutai Timur. Selain perbedaan mengenai hasil koefisien determinan variabel independen dalam menjelaskan efektivitas organisasi, terdapat pula hasil yang berbeda dalam hal arah hubungan antara variabel independen dengan variabel dependennya. Dalam penelitian yang dilakukan oleh Waworuntu (2016) dalam penelitian kuantitatifnya pada Dinas Dukcapil Kabupaten Minahasa Selatan, menunjukkan bahwa struktur organisasi berpengaruh positif terhadap efektivitas organisasi. Hasil positif juga diperlihatkan oleh penelitian Gammahendra (2014) pada Kantor Perwakilan Bank Indonesia. Namun hasil yang berlawanan arah ditunjukkan oleh Zheng (2009) dengan menggunakan SEM dimana struktur organisasi mempunyai hubungan yang negatif terhadap efektivitas organisasi.

Selain dua variabel yang telah tersebut di atas, hal yang sama juga dapat dilihat dari variabel kemampuan SDM dan motivasi. Dalam penelitian Prasetyaningsih (2009), kemampuan SDM yang berpasangan dengan kepemimpinan dan struktur organisasi hanya dapat menjelaskan efektivitas organisasi sebesar 26,52 persen. Di sisi lain dalam penelitian Rofai (2006), ternyata kemampuan personal (SDM) yang digabungkan dengan motivasi 
dan kepemimpinan ternyata justru dapat menjelaskan efektivitas organisasi sebesar 47,5 persen.

Dalam hierarki desentralisasi tanggung jawabnya, BPS di daerah diwakili oleh BPS Provinsi dan BPS Kabupaten/Kota. Salah satu instansi yang menjadi wakil pelaksanaan perstatistikan nasional di wilayah Provinsi Nusa Tenggara Barat adalah BPS Provinsi Nusa Tenggara Barat yang terdiri dari sepuluh BPS Kabupaten/Kota (delapan kabupaten dan dua kota).

Dari sepuluh BPS Kabupaten/Kota tersebut, terdapat tiga BPS Kabupaten/Kota yang memperoleh penghargaan instansi terbaik di lingkup BPS se-Provinsi NTB Tahun 2016. Secara berurutan dari peringkat pertama adalah BPS Kota Mataram, BPS Kota Bima dan BPS Kabupaten Sumbawa Barat. Dari ketiga BPS Kabupaten/Kota tersebut berdasarkan klasifikasi beban kerjanya menunjukkan satu BPS Kabupaten/Kota bertipe B (beban kerja sedang) dan dua lainnya bertipe C (beban kerja kecil). Dalam komposisi tiga peringkat terbaik tersebut, terlihat bahwa semua instansi di lingkup BPS Kabupaten/Kota se-NTB punya peluang yang sama dalam meraih penghargaan yang dinilai dari sejauh mana mencapai efektivitas organisasinya.

Berdasarkan informasi yang peneliti dapatkan dari Kepala Bidang Tata Usaha BPS Provinsi NTB, 3 peringkat terbaik BPS Kabupaten/Kota tersebut tidak luput dari permasalahan. Walaupun mendapat capaian yang bagus, ternyata masih menyisakan permasalahan dari segi internal maupun eksternal organisasi. Ditambahkan pula bahwa permasalahan yang dihadapi oleh peraih 3 peringkat terbaik tersebut, dihadapi pula oleh tujuh BPS Kabupaten/Kota lainnya dengan kadar yang berbeda. Adapun permasalahan yang muncul tersebut adalah sebagai berikut :

1. Kurangnya penegakan disiplin dari pimpinan terhadap pegawai yang tidak taat aturan dalam ketepatan jam kerja

2. Kurangnya koordinasi baik antar pegawai maupun antar sub bagian/seksi

3. Penempatan pegawai dalam struktur organisasi dan tata kerja yang belum sesuai dengan pendidikan, pengalaman dan kemampuan kerjanya

4. Kurangnya pendidikan dan pelatihan keterampilan pegawai; dan terbatasnya sumber daya manusia yang berkualitas

5. Rendahnya motivasi pegawai terhadap keberlangsungan efektivitas organisasi.

Melihat fakta permasalahan organisasi yang muncul tersebut, apabila kita kaitkan dengan faktor-faktor efektivitas organisasi maka diperkirakan faktor kepemimpinan, struktur organisasi, kemampuan SDM, dan motivasi yang menjadi sumbernya.

Berdasarkan pada hasil fenomena temuan di lapangan dan riset gap dari penelitianpenelitian sebelumnya tersebut, diperlukan suatu penelitian untuk menganalisis faktorfaktor yang mempengaruhi efektivitas organisasi di BPS Kabupaten/Kota se-Provinsi Nusa Tenggara Barat. Sehingga didapatkan hasil yang berguna bagi instansi terkait dalam memodelkan maupun melakukan kebijakan terkait faktor-faktor yang mempengaruhi efektivitas organisasi pada BPS Kabupaten/Kota se-NTB. Adapun masalah penelitian dirumuskan sebagai berikut:

1. Apakah kepemimpinan mempengaruhi efektivitas organisasi pada BPS Kabupaten/Kota se-NTB?

2. Apakah struktur organisasi mempengaruhi efektivitas organisasi pada BPS Kabupaten/Kota se-NTB?

3. Apakah kemampuan SDM mempengaruhi efektivitas organisasi pada BPS Kabupaten/Kota se-NTB? 
4. Apakah motivasi mempengaruhi efektivitas organisasi pada BPS Kabupaten/Kota se-NTB ?

5. Bagaimana kecenderungan pengaruh masing-masing variabel bebas terhadap efektivitas organisasi pada BPS Kabupaten/Kota se-NTB?

\section{Kerangka Teoritis}

\subsection{Landasan teori}

\subsubsection{Efektivitas Organisasi}

Gibson (1996) mengatakan efektivitas menggambarkan seluruh siklus input-prosesoutput. Sedangkan organisasi adalah sekumpulan orang yang mempunyai arah dan tujuan yang sama. Oleh karena itu, dapat disimpulkan bahwa efektivitas organisasi merupakan susunan dari beberapa orang secara rapi yang menggambarkan seluruh siklus inputproses-output untuk mencapai tujuan yang diharapkan.

Siagian (1982) mengatakan bahwa organisasi adalah setiap bentuk persekutuan antara dua orang atau lebih yang bekerjasama secara formal terikat dalam rangka pencapaian suatu tujuan yang telah ditentukan, dalam ikatan mana terdapat seorang/beberapa orang yang disebut bawahan. Organisasi dapat pula didefinisikan sebagai suatu himpunan interaksi manusia yang bekerjasama untuk mencapai tujuan bersama yang terikat dalam suatu ketentuan yang telah disetujui bersama.

Katz dan Kahn dalam Steers (1985) mengatakan bahwa untuk memastikan keberhasilan akhir, suatu organisasi harus dapat memenuhi tiga persyaratan perilaku penting yaitu :

1. Organisasi harus mampu membina dan mempertahankan suatu armada kerja yang mantap terdiri dari personil terampil

2. Organisasi harus dapat menikmati prestasi peranan yang dapat diandalkan dari para personilnya, dalam hal ini setiap personil bukan saja dituntuk untuk bersedia berkarya, tetapi juga harus melaksanakan tugas khusus yang menjadi tanggung jawab utamanya

3. Para personil harus mengusahakan bertingkah laku yang spontan dan inovatif, dengan demikian setiap personil jangan hanya bertingkahlaku secara pasif saja.

\subsubsection{Kepemimpinan}

Menurut Rivai (2004:64) kepemimpinan pada dasarnya mempunyai pokok pengertian sebagai sifat, kemampuan, proses, dan atau konsep yang dimiliki oleh seseorang sedemikian rupa sehingga ia diikuti, dipatuhi, dihormati dan orang lain bersedia dengan penuh keikhlasan melakukan perbuatan atau kegiatan yang telah dikehendaki oleh pemimpin tersebut. Siagian (1982) berpendapat bahwa kepemimpinan adalah keterampilan dan kemampuan seseorang mempengaruhi perilaku orang lain, baik yang kedudukannya lebih tinggi maupun lebih lebih rendah daripadanya dalam berfikir dan bertindak agar perilaku yang semula mungkin individualistik dan egosentrik berubah menjadi perilaku organisasional. Dalam suatu organisasi, kepemimpinan merupakan salah satu faktor utama yang mendukung kesuksesan organisasi dalam mencapai tujuan. Gibson (1996) mendefinisikan organisasi sebagai wadah yang memungkinkan masyarakat dapat meraih hasil yang sebelumnya tidak dapat dicapai oleh individu secara sendiri-sendiri.

Davis dalam Handoko (2000) merumuskan 4 sifat umum yang berpengaruh terhadap keberhasilan kepemimpinan organisasi, antara lain: 
a. Kecerdasan

Berdasarkan hasil penelitian, pemimpin yang mempunyai kecerdasan yang tinggi di atas kecerdasan rata-rata dari pengikutnya akan mempunyai kesempatan berhasil yang lebih tinggi pula.

b. Kedewasaan dan keluasan hubungan sosial

Umumnya di dalam melakukan interaksi sosial dengan lingkungan internal maupun eksternal, seorang pemimpin yang berhasil mempunyai emosi yang matang dan stabil.

c. Motivasi diri dan dorongan berprestasi

Seorang pemimpin yang berhasil umumnya memiliki motivasi diri yang tinggi serta dorongan untuk berprestasi.

d. Sikap hubungan kemanusiaan

Adanya pengakuan terhadap harga diri dan kehormatan sehingga para pengikutnya mampu berpihak kepadanya.

\subsubsection{Struktur Organisasi}

Struktur adalah susunan berupa kerangka yang memberikan bentuk dan wujud, dengan demikian akan terlihat prosedur kerjanya. Dalam organisasi pemerintahan, prosedur merupakan suatu rangkaian tindakan yang ditetapkan lebih dulu, yang harus dilalui untuk mengerjakan suatu tugas. Sementara itu dalam konsep lain oleh Meter dan Horn dalam Winarno (1997) dikatakan bahwa struktur organisasi juga dapat diartikan sebagai suatu hubungan karakteristik-karakteristik, norma-norma dan pola-pola hubungan yang terjadi di dalam badan-badan eksekutif yang mempunyai hubungan baik potensial atau nyata dengan apa yang mereka miliki dalam menjalankan kebijaksanaan. Pengertian ini sejalan dengan apa yang dikemukakan oleh Robbins (2010) bahwa struktur organisasi menetapkan bagaimana tugas akan dibagi, siapa melapor kepada siapa, mekanisme koordinasi yang formal serta pola interaksi yang akan diikuti. Lebih jauh Robbins mengatakan bahwa struktur organisasi mempunyai tiga komponen yaitu : kompleksitas, formalisasi dan sentralisasi. Kompleksitas berarti dalam struktur orgaisasi mempertimbangkan tingkat differensiasi yang ada dalam organisasi termasuk di dalamnya tingkat spesialisasi atau pembagian kerja, jumlah tingkatan dalam organisasi serta tingkat sejauh mana unit-unit organisasi tersebar secara geografis. Formalisasi berarti dalam struktur organisasi memuat tentang tata cara atau prosedur bagaimana suatu kegiatan itu dilaksanakan (Standard Operating Procedures), apa yang boleh dan tidak dapat dilakukan. Sentralisasi berarti dalam struktur organisasi memuat tentang kewenangan pengambilan keputusan, apakah disentralisasi atau didesentralisasi.

\subsubsection{Kemampuan SDM}

Menurut Simamora (1995) manajemen sumber daya manusia adalah pemberdayaan, pengembangan, penilaian, pemberian balas jasa, dan pengelolaan individu anggota organisasi atau kelompok pekerja. Manajemen sumber daya manusia yang efektif mengharuskan manajer menemukan cara terbaik dalam mengkaryakan orang-orang agar mencapai tujuan yang diinginkan dan meningkatkan kinerja organisasi.

Menurut Flipplo dalam Handoko (2000) manajemen sumber daya manusia adalah perencanaan, pengorganisasian, pengarahan, dan pengawasan kegiatan, pengembangan, pemberian konpensasi, pengintegrasian, memelihara dan pelepasan SDM agar tercapai tujuan organisasi. Tercapainya tujuan suatu organisasi sangat tergantung dari kemampuan sumber daya manusia dalam memiliki pengetahuan dan ketrampilan dalam bidang yang menjadi tanggung jawabnya. Karena hal ini akan mendorong tercapainya tujuan organisasi dengan lebih cepat, efektif, dan efesien. 
Menurut Handoko (2000) manajemen sumber daya manusia adalah penarikan, seleksi, pengembangan, pemeliharaan, dan penggunaan sumber daya manusia untuk mencapai tujuan baik individu-individu maupun organisasi. Kemampanan suatu organisasi sangat bergantung pada ketersediaan dan kemampuan Sumber Daya Manusia (SDM) dalam melaksanakan tugas atau pekerjaan. Karena hal ini akan mendorong tercapainya tujuan organisasi dengan lebih cepat, efektif dan efisien, sehingga dengan sendirinya organisasi akan selalu siap menghadapi dan beradaptasi dengan setiap perubahan yang ada, khususnya yang berhubungan dengan usaha kearah pengembangan organisasi.

\subsubsection{Motivasi}

Motivasi dapat diartikan sebagai usaha yang dapat mendorong dan menolak seseorang atau sekelompok orang untuk bertindak sesuai yang diharapkan, sehingga dapat tercapai tujuan organisasi secara efektif dan efisien. Mangkuprawira (2007) menjelaskan bahwa motivasi merupakan dorongan yang membuat karyawan melakukan sesuatu dengan cara dan untuk mencapai tujuan tertentu, motivasi itu timbul tidak saja karena ada unsur di dalam dirinya, tetapi juga karena adanya stimulus dari luar, seberapapun tingkat kemampuan yang dimiliki seseorang pasti membutuhkan motivasi.

Dalam analisis individu, motivasi adalah keadaan dalam diri seseorang yang mendorong keinginan individu untuk melakukan kegiatan-kegiatan tertentu guna mencapai tujuan ( Handoko, 2000). Jadi motivasi yang ada pada seseorang akan mewujudkan suatu perilaku yang diarahkan pada tujuan mencapai sasaran kepuasan. Motivasi diawali dengan keinginan untuk mempengaruhi perilaku seseorang, keinginan tersebut diwujudkan melalui proses jawaban yang diterima oleh seseorang dengan ditentukan oleh kepribadian, sikap, pengalaman, dan harapan seseorang. Selanjutnya apa yang diterima tersebut diberi arti oleh yang bersangkutan menurut minat dan keinginan (faktor intrinsik).

\subsection{Hubungan Antar Variabel}

\subsubsection{Pengaruh Kepemimpinan Terhadap Efektivitas Organisasi}

Menurut Davis dalam Handoko (2000), kepemimpinan yang dapat mempengaruhi suksesnya efektivitas organisasi adalah ketika pemimpin di dalam organisasi tersebut memiliki kemampuan intelegensia, kematangan dan keluasan pendangan sosial, sehingga mampu mengendalikan keadaan yang kritis dan mempunyai keyakinan serta kepercayaan pada diri sendiri, mempunyai motivasi dan keinginan berprestasi yang datang dari dalam, mempunyai kemampuan mengadakan hubungan antar manusia. Jadi keberhasilan suatu organisasi dalam mencapai tujuannya juga ditentukan oleh kemampuan yang dimiliki oleh seorang pemimpin organisasi.

Lebih jauh lagi, menurut Vroom dan Yetton dalam Yukl (1994) bahwa pemimpin juga harus pandai dalam membuat suatu keputusan secara tepat dan efektif untuk mencapai efektivitas organisasi yang diinginkan. Selain itu, Thahier (2016), Prasetyaningsih (2009), dan Rofai (2009) dalam penelitiannya menunjukkan hasil bahwa kepemimpinan mempunyai pengaruh yang positif dan signifikan terhadap efektivitas organisasi. Berdasarkan kajian penelitian terdahulu ini, maka dapat dirumuskan hipotesa pertama:

$\mathrm{H}_{1}$ : Diduga kepemimpinan berpengaruh signifikan terhadap efektivitas organisasi pada BPS Kabupaten/Kota se-NTB.

\subsubsection{Pengaruh Struktur Organisasi Terhadap Efektivitas Organisasi}

Menurut pendapat Robbins (2010) bahwa struktur organisasi sangat berperan dalam meningkatkan efektivitas organisasi. Hal ini karena di dalam struktur organisasi terdapat beberapa mekanisme koordinasi yang formal, bagaimana pendelegasian tugas 
dilaksanakan dan bagaimana interaksi dilakukan. Hal tersebut sangat mempengaruhi suatu organisasi dalam mencapai tujuannya. Lebih jauh lagi, Siagian dalam Prasetyaningsih (2009) mengemukakan bahwa organisasi adalah bentuk persekutuan formal yang terikat dalam rangka pencapaian tujuan yang telah ditentukan. Pencapaian tujuan tersebut adalah wujud dari efektivitas organisasi, sehingga pola bagaimana interaksi atasan terhadap bawahan dan sebaliknya dalam struktur organisai akan mempengaruhi efektivitas organisasi.

Berdasarkan hasil penelitian terkait hubungan antara struktur organisasi terhadap efektivitas organisasi. Penelitian Wawarontu (2016), Prasetyaningsih (2009) dan Gammahendra (2014) memperlihatkan bahwa struktur organisasi mempunyai pengaruh yang positif dan signifikan terhadap efektivitas organisasi. Sehingga baiknya suatu susunan organisasi akan berimbas baik pula pada tercapainya efektivitas organisasi. Berdasarkan kajian penelitian terdahulu ini, maka dapat dirumuskan hipotesa kedua:

$\mathrm{H}_{2}$ : Diduga struktur organisasi berpengaruh signifikan terhadap efektivitas organisasi pada BPS Kabupaten/Kota se-NTB.

\subsubsection{Pengaruh Kemampuan SDM Terhadap Efektivitas Organisasi}

Menurut Flipplo dalam Handoko (2000), manajemen sumber daya manusia adalah perencanaan, pengorganisasian, pengarahan, dan pengawasan kegiatan, pengembangan, pemberian kompensasi, pengintegrasian, memelihara dan pelepasan SDM agar tercapai tujuan organisasi. Tercapainya tujuan suatu organisasi sangat tergantung dari kemampuan sumber daya manusia dalam memiliki pengetahuan dan keterampilan dalam bidang yang menjadi tanggung jawabnya. Karena hal ini akan mendorong tercapainya tujuan organisasi dengan lebih cepat, efektif, dan efesien.

Prasetyaningsih (2009), dalam penelitiannya memperlihatkan bahwa kemampuan SDM sangat berpengaruh terhadap efektivitas organisasi. Kemampuan SDM merupakan modal yang strategis demi meraih efektivitas organisasi yang jauh lebih baik. Berdasarkan kajian penelitian terdahulu ini, maka dapat dirumuskan hipotesa ketiga:

$\mathrm{H}_{3}$ : Diduga kemampuan SDM berpengaruh signifikan terhadap efektivitas organisasi pada BPS Kabupaten/Kota se-NTB.

\subsubsection{Pengaruh Motivasi Terhadap Efektivitas Organisasi}

Mangkuprawira (2007) menjelaskan bahwa motivasi merupakan dorongan yang membuat karyawan melakukan sesuatu dengan cara dan untuk mencapai tujuan tertentu, motivasi itu timbul tidak saja karena ada unsur di dalam dirinya, tetapi juga karena adanya stimulus dari luar, seberapapun tingkat kemampuan yang dimiliki seseorang pasti membutuhkan motivasi. Selanjutnya Robbins (2010) mengemukakan bahwa motivasi adalah kesediaan untuk mengeluarkan tingkat upaya yang tinggi ke arah tujuan organisasi yang dikondisikan oleh kemampuan upaya itu dalam memenuhi sesuatu kebutuhan individual. Motivasi adalah faktor pendorong dalam diri seorang untuk bekerja secara optimal, sehingga keinginan yang ada pada anggota organisasi dan tujuan organisasi sekaligus dapat tercapai. Dalam kaitannya dengan efektivitas organisasi maka dapat dikatakan bahwa motivasi perseorangan dalam suatu organisasi berdampak langsung pada arah pencapaian tujuan organisasi, karena prestasi kerja atau kinerja individual yang didorong oleh motivasi secara otomatis akan mempengaruhi kinerja organisasi dalam mencapai tujuan yang telah ditetapkan, sehingga efektivitas organisasi dapat tercapai.

Rofai (2006) dan Salabi (2015) memperlihatkan dalam penelitiannya bahwa motivasi mempunyai hubungan yang positif terhadap efektivitas organisasi. Motivasi yang dimiliki oleh pegawai akan sangat menentukan bagaimana efektivitas organisasi dapat terwujud dengan baik. Semakin tinggi motivasi pegawai maka akan berdampak baik kepada 
percepatan efektivitas organisasinya. Berdasarkan kajian penelitian terdahulu ini, maka dapat dirumuskan hipotesa keempat:

$\mathrm{H}_{4}$ : Diduga motivasi berpengaruh signifikan terhadap efektivitas organisasi pada BPS Kabupaten/Kota se-NTB.

\subsection{Kerangka Konseptual}

Efektivitas organisasi adalah kapasitas suatu organisasi untuk memperoleh dan memanfaatkan sumber dayanya yang langka dan berharga secara sepadan dalam usahanya mengejar tujuan organisasi dan operasionalnya. Beberapa faktor yang mempengaruhinya diantaranya adalah kepemimpinan, struktur organisasi, kemampuan SDM, dan motivasi. Kepemimpinan mempengaruhi efektivitas organisasi didukung oleh Davis dalam Handoko (2000), Vroom dan Yetton dalam Yukl (1994), dan hasil penelitian yang dilakukan oleh Thahier (2016), Prasetyaningsih (2009), dan Rofai (2006). Struktur organisasi mempengaruhi efektivitas organisasi didukung oleh Robbins (2010), Siagian dalam Prasetyaningsih (2009), dan hasil penelitian yang dilakukan oleh Wawarontu (2016), Prasetyaningsih (2009) dan Gammahendra (2014). Kemampuan SDM mempengaruhi efektivitas organisasi didukung oleh Flippo dalam Handoko (2000) dan hasil penelitian yang dilakukan oleh Prasetyaningsih (2009). Motivasi mempengaruhi efektivitas organisasi didukung oleh Mangkuprawira (2007), Handoko (2000), Robbins (2010) dan hasil penelitian yang dilakukan oleh Rofai (2006) dan Salabi (2015). Dengan demikian apabila digambarkan maka kerangka konseptualnya adalah sebagai berikut :

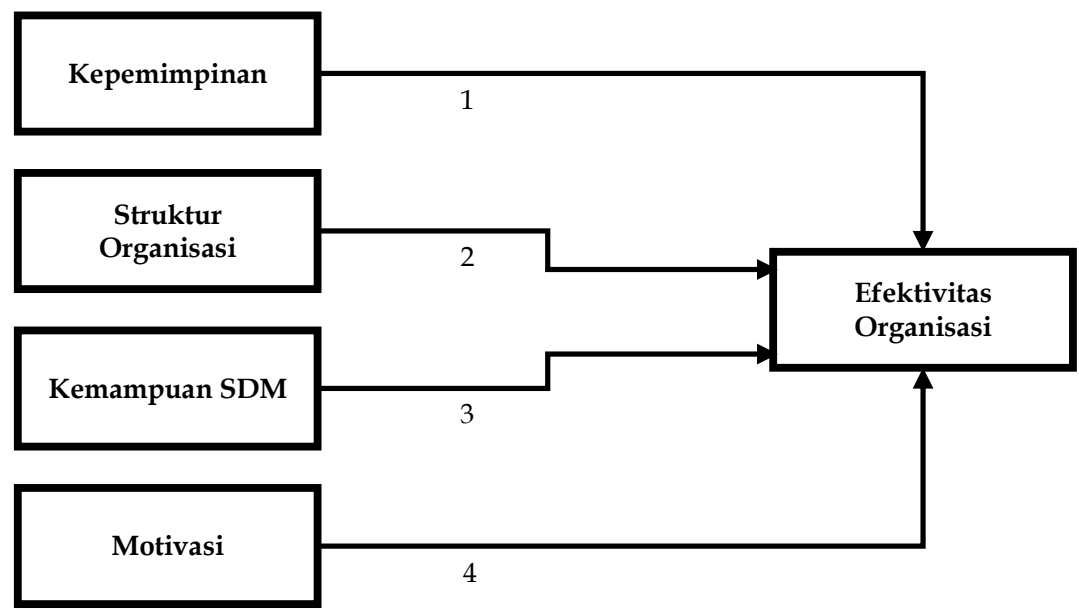

Keterangan : 1. Davis dalam Handoko (2000), Vroom dan Yetton dalam Yukl (1994)

2. Robbins (2010), Siagian dalam Prasetyaningsih (2009)

3. Flippo dalam Handoko (2000)

3. Metode Penelitian

4. Mangkuprawira (2007), Handoko (2000), Robbins (2010)

Berdasarkan sifat dari masalah yang dihadapi dan tujuan penelitian yang direncanakan, maka jenis penelitian yang digunakan dalam penelitian ini adalah penelitian kuantitatif deskriptif. Populasi dalam penelitian ini adalah semua pegawai yang berstatus ASN dari 10 organisasi di BPS Kabupaten/Kota se-Nusa Tenggara Barat sebanyak 255 orang. Kemudian dilakukan pengambilan sampel dengan teknik probability sampling menggunakan metode sampling gugus/klaster sehingga mendapatkan responden sebanyak 128 dari 5 organisasi (gugus). Kuesioner disebarkan kepada semua responden untuk mendapatkan data penelitian. 
Variabel efektivitas organisasi diukur dengan menggunakan indikator yang dikembangkan oleh Steers (1985), variabel kepemimpinan dengan menggunakan indikator yang dikembangkan oleh Davis dalam Handoko (2000), Vroom dan Yetton dalam (1994), Prasetyaningsih (2009), dan Rofai (2006), variabel struktur organisasi dengan menggunakan indikator yang dikembangkan oleh Robbins (2010), Siagian dalam Prasetyaningsih (2009), dan Rofai (2006), variabel kemampuan SDM dengan menggunakan indikator yang dikembangkan oleh Flipplo dalam Handoko (2000), Prasetyaningsih (2009), dan Rofai (2006), dan variabel motivasi dengan menggunakan indikator yang dikembangkan oleh Mangkuprawira (2007), Handoko (2000), Robbins (2010), Rofai (2006), dan Salabi (2005).

Dalam memberikan pembobotan pada masing-masing variabel digunakan skala lima tingkat yang terdiri dari sangat setuju, setuju, kurang setuju, tidak setuju dan sangat tidak setuju (Sugiyono, 2009). Dalam analisis regresi logistik, diperlukan konversi nilai skala likert dari hasil instrumen pertanyaan ke dalam dua klasifikasi untuk memenuhi proses analisisnya. Prosesnya adalah dengan membuat semua variabel yang dipakai dalam penelitian ini diklasifikasikan menjadi dua kategori menggunakan nilai rata-ratanya (ratarata aktual). Prosedur ini sesuai dengan pendapat yang dikemukakan Azwar (2009), yaitu bahwa suatu cara untuk memberikan interpretasi terhadap skor individual dalam skala rating yang dijumlahkan adalah dengan membandingkan skor tersebut dengan harga ratarata atau mean skor kelompok dimana responden itu termasuk. Adapun rincian dari pengkategorian tersebut dapat dilihat pada tabel berikut:

Tabel 1. Kategorisasi Kepemimpinan, Struktur Organisasi, Kemampuan SDM, Motivasi dan Efektivitas Organisasi

\begin{tabular}{|l|l|l|}
\hline \multicolumn{1}{|c|}{ Variabel } & \multicolumn{1}{|c|}{ Ketegori } & \multicolumn{1}{c|}{ Batasan Skor } \\
\hline \multirow{2}{*}{ Kepemimpinan } & \multicolumn{1}{|c|}{$(2)$} & \multicolumn{1}{c|}{$(3)$} \\
\hline \multirow{2}{*}{ Struktur Organisasi } & Baik & $>19,27$ \\
\cline { 2 - 3 } & Buruk & $\leq 19,27$ \\
\hline \multirow{2}{*}{ Kemampuan SDM } & Baik & $>15,66$ \\
\cline { 2 - 3 } & Buruk & $\leq 15,66$ \\
\hline \multirow{2}{*}{ Motivasi } & Baik & $>21,33$ \\
\cline { 2 - 3 } & Buruk & $>21,33$ \\
\hline \multirow{2}{*}{ Efektivitas Organisasi } & Tinggi & $\leq 18,62$ \\
\cline { 2 - 3 } & Rendah & $>36,02$ \\
\hline & Baik & $\leq 36,07$ \\
\cline { 2 - 3 } & Buruk & \\
\hline
\end{tabular}

Sumber : Data primer diolah, 2017

Sebelum melakukan penelitian dilakukan uji pilot untuk melihat validitas dan reliabilitas instrument penelitian. Hasil uji validitas dan reliabilitas instrumen penelitian menunjukkan bahwa semua item variabel penelitian yang digunakan reliabel karena nilai Cronbach's Alpha-nya di atas 0,8 (kategori tinggi). Selanjutnya hasil uji validitas instrumen penelitian menunjukkan bahwa dari 33 item semua item variabel penelitian yang digunakan valid, kecuali dua item pada indikator variabel kepemimpinan dan dua item pada indikator variabel struktur organisasi karena nilai $r$ hitungnya kurang dari 0,302. Untuk pengumpulan datanya dilakukan dengan 30 item pertanyaan yang valid dan reliabel. Analisis data dalam penelitian ini menggunakan uji staistik deskriptif dan analisis regresi logistik. 


\section{Hasil Penelitian dan Pembahasan}

4.1. Karakteristik Responden

Tabel 2. Komposisi Responden Penelitian Berdasarkan Jenis Kelamin

\begin{tabular}{|c|c|c|c|c|c|c|}
\hline \multirow{2}{*}{ No } & \multirow{2}{*}{ Unit Kerja } & \multicolumn{2}{|c|}{$\begin{array}{c}\text { Jenis } \\
\text { Kelamin }\end{array}$} & \multirow{2}{*}{$\begin{array}{l}\text { Jumlah } \\
\text { Responden }\end{array}$} & \multicolumn{2}{|c|}{ Persentase (\%) } \\
\hline & & $\mathbf{L}$ & $\mathbf{P}$ & & $\mathbf{L}$ & $\mathbf{P}$ \\
\hline$(1)$ & (2) & (3) & $(4)$ & $(5)$ & (6) & (7) \\
\hline 1 & BPS Kab. Lombok Barat & 22 & 8 & 30 & 73.33 & 26.67 \\
\hline 2 & BPS Kab. Lombok Timur & 23 & 11 & 34 & 67.65 & 32.35 \\
\hline 3 & BPS Kab. Dompu & 16 & 6 & 22 & 72.73 & 27.27 \\
\hline 4 & $\begin{array}{lll}\text { BPS } & \text { Kab. } & \text { Sumbawa } \\
\text { Barat } & & \end{array}$ & 13 & 4 & 17 & 76.47 & 23.53 \\
\hline 5 & BPS Kota Mataram & 12 & 13 & 25 & 48.00 & 52.00 \\
\hline & Jumlah & 86 & 42 & 128 & 67.19 & 32.81 \\
\hline
\end{tabular}

Berdasarkan tabel 2 di atas terlihat bahwa responden penelitian di BPS Kabupaten/Kota se-Nusa Tenggara Barat didominasi oleh laki-laki sebesar 67,19 persen. Namun jika dilihat dari 5 organisasi yang menjadi sampel penelitian, terlihat BPS Kota Mataram mempunyai jumlah pegawai perempuan yang lebih banyak daripada pegawai laki-laki. Terkait dengan peningkatan partisipasi perempuan dalam dunia kerja, maka dalam hal ini peneliti berasumsi bahwa tidak ada perbedaan yang berarti dalam pencapaian efektivitas organisasi antara laki-laki dan perempuan.

Tabel 3. Komposisi Responden Berdasarkan Umur

\begin{tabular}{|c|c|r|r|}
\hline No & Umur (tahun) & Jumlah Responden & \multicolumn{2}{|c|}{ Persentase (\%) } \\
\hline$(1)$ & $(2)$ & $(3)$ & $(4)$ \\
\hline 1 & 21 s.d 30 & 29 & 22.66 \\
\hline 2 & 31 s.d 40 & 44 & 34.38 \\
\hline 3 & 41 s.d 50 & 20 & 15.63 \\
\hline 4 & 51 ke atas & 35 & 27.34 \\
\hline \multicolumn{2}{|r|}{ Jumlah } & $\mathbf{1 2 8}$ & $\mathbf{1 0 0 . 0 0}$ \\
\hline
\end{tabular}

Berdasarkan tabel 3 di atas dapat dilihat bahwa responden penelitian di BPS Kabupaten/Kota se-Nusa Tenggara Barat yang terbanyak pada kelompok umur 31 sampai dengan 40 tahun yaitu sebanyak 44 orang atau 34,38 persen. Sedangkan kelompok umur yang paling sedikit adalah kelompok umur 41 sampai dengan 50 tahun yaitu sebanyak 20 orang atau 15,63 persen.

Tabel 4. Komposisi Responden Berdasarkan Pendidikan Terakhir

\begin{tabular}{|c|l|r|r|}
\hline No & \multicolumn{1}{|c|}{ Pendidikan Terakhir } & Jumlah Responden & \multicolumn{2}{|c|}{ Persentase (\%) } \\
\hline$(1)$ & $(2)$ & 39 & 30.47 \\
\hline 1 & <=SMA & 11 & 8.59 \\
\hline 2 & DI, DII, DIII & 75 & 58.59 \\
\hline 3 & DIV/S1 & 3 & 2.34 \\
\hline 4 & S2/S3 & $\mathbf{1 2 8}$ & $\mathbf{1 0 0 . 0 0}$ \\
\hline \multicolumn{2}{c|}{ Jumlah }
\end{tabular}


Dari tabel 4 di atas dapat kita lihat bahwa responden penelitian di BPS Kabupaten/Kota se-Nusa Tenggara Barat didominasi oleh lulusan Diploma IV dan Sarjana Strata 1 yaitu sebanyak 75 orang atau 58,59 persen. Sedangkan yang paling sedikit adalah lulusan Sarjana Strata 2 dan 3 yaitu sebanyak 3 orang atau 2,34 persen.

\subsection{Analisis Data}

\subsubsection{Likelihood Ratio Test atau Uji Simultan}

Uji simultan digunakan untuk mengetahui pengaruh seluruh variabel bebas di dalam model secara bersama-sama. Pengujian ini dapat dilakukan dengan menghitung statistik uji-G. Karena nilai statistik uji G $(96,498)$ lebih besar daripada $\chi^{\wedge} 2(4 ; 0,05)=9,488$, maka dapat diambil kesimpulan bahwa minimal ada satu variabel bebas yang berpengaruh terhadap efektivitas organisasi pada BPS Kabupaten/Kota se-Nusa Tenggara Barat.

\subsubsection{Negalgarke R-Square dan Classification Plot}

Tabel 5. Nilai Negalgarke R-Square dan Classification Plot

\begin{tabular}{|l|l|}
\hline Uraian & Nilai \\
\hline Negalgarke R-Square & 0,767 \\
Overall Classification plot & 96,1 \\
\hline
\end{tabular}

Negalgarke R-Square memiliki intepretasi yang mirip dengan koefisien determinasi pada regresi liner. Dengan demikian terlihat bahwa efektivitas organisasi di BPS Kabupaten/Kota se-Nusa Tenggara Barat dapat dijelaskan oleh model sebesar 76,7 persen. Atau secara lebih jelas dapat menggunkan nilai Overral Classification Plotnya yaitu sebesar 96,1, sehingga dapat dikatakan bahwa model regresi logistik yang dihasilkan dapat digunakan dengan baik, karena mampu menebak dengan benar pada 96,1 persen kondisi yang sebenarnya.

\subsubsection{Uji Wald atau Uji Parsial}

Tabel 6. Nilai Penduga Parameter, Statistik Uji Wald, dan Signifikansi dari Variabel Bebas dan Konstanta

\begin{tabular}{|l|c|c|c|}
\hline \multicolumn{1}{|c|}{ Variabel } & $\widehat{\boldsymbol{\beta}}$ & Wald & Sig. \\
\hline Kepemimpinan & 1,506 & 3,776 & 0,052 \\
Struktur Organisasi & 2,654 & 10,380 & 0,001 \\
Kemampuan SDM & 2,348 & 9,610 & 0,002 \\
Motivasi & 2,299 & 8,919 & 0,003 \\
Konstanta & $-3,221$ & 15,862 & 0,000 \\
\hline
\end{tabular}

Variabel Dependen : Efektivitas Organisasi

Berdasarkan tabel 6 di atas dapat diketahui bahwa variabel bebas yang bisa dimasukkan dalam model persamaan regresi logistik yang akan terbentuk adalah variabel struktur organisasi, kemampuan SDM, dan motivasi. Sedangkan variabel kepemimpinan tidak masuk ke dalam model karena nilai wald $(3,776)$ lebih rendah dari nilai kritis uji wald $\left(\chi_{(2 ; 0,05)}^{2}=5,991\right)$ atau nilai signifikansinya $(0,052)$ lebih besar dari nilai a $(0,05)$. Sehingga dapat disimpulkan bahwa variabel kepemimpinan berpengaruh positif namun tidak signifikan secara statistik terhadap efektivitas organisasi sehingga variabel tersebut tidak bisa dimasukkan ke dalam persamaan regresi logistik. 


\subsubsection{Rasio Kecenderungan (Odd Ratio)}

Tabel 7. Nilai Odds Ratio Variabel Bebas

\begin{tabular}{|l|c|}
\hline \multicolumn{1}{|c|}{ Variabel } & Odds Ratio \\
\hline Struktur Organisasi & 14,22 \\
Kemampuan SDM & 10,47 \\
Motivasi & 9,96 \\
Konstanta & 0,04 \\
\hline
\end{tabular}

Berdasarkan tabel 7 diperoleh nilai odds ratio untuk variabel struktur organisasi yaitu sebesar 14,22. Artinya bahwa kecenderungan seorang pegawai yang struktur organisasinya telah berjalan dengan baik akan melakukan efektivitas organisasi yang baik pula sebesar 14,22 kali bila dibandingkan dengan kecenderungan pegawai yang menyatakan bahwa struktur organisasinya berjalan buruk. Temuan yang diperoleh dalam odds ratio ini memperkuat analisis deskriptif yang sebelumnya telah menyebutkan bahwa pegawai yang memiliki kemampuan menciptakan efektivitas organisasi yang baik cenderung dimiliki oleh pegawai yang menyatakan struktur organisasinya telah berjalan dengan baik. Untuk selanjutnya variabel kemampuan SDM nilai odds ratio-nya sebesar 10,47 dan variabel motivasi sebesar 9,96.

\subsection{Pembahasan Hasil Penelitian}

\subsubsection{Pengaruh Kepemimpinan Terhadap Efektivitas Organisasi di BPS Kabupaten/Kota se-Nusa Tenggara Barat}

Dalam berbagai literatur dan penelitian terdahulu disebutkan bahwa kepemimpinan merupakan salah satu variabel yang mempengaruhi efektivitas organisasi, namun dalam penelitian ini ditemukan hasil yang berbeda, dimana kepemimpinan di BPS Kabupaten/Kota se-Nusa Tenggara Barat berpengaruh positif namun tidak signifikan terhadap efektivitas organisasinya. Dengan kata lain, bahwa hasil penelitian ini bertentangan dengan teori-teori yang ada dan tidak mendukung hasil-hasil penelitian sebelumnya yang menemukan bahwa ada hubungan positif dan signifikan antara kepemimpinan dan efekivitas organisasi, dimana semakin baik kepemimpian di dalam organisasi maka akan meningkatkan efektivitas organisasinya, seperti penelitian yang dilakukan oleh Thahier (2016), Salabi (2015), Amuniansyah (2014), Prasetyaningsih (2009) dan Rofai (2006).

Dari nilai koefisien beta di dalam model regresi logistik yang dihasilkan, variabel kepemimpinan mempunyai nilai yang paling rendah dibandingkan dengan variabel lainnya yaitu 1,506. Sehingga hal ini dapat menggambarkan bahwa pengaruh variabel kepemimpinan paling rendah dibandingkan struktur organisasi, kemampuan SDM, dan motivasi terhadap efektivitas organisasi di BPS Kabupaten/Kota se-Nusa Tenggara Barat.

\subsubsection{Pengaruh Struktur Organisasi Terhadap Efektivitas Organisasi di BPS Kabupaten/Kota se-Nusa Tenggara Barat}

Hasil penelitian ini mengindikasikan bahwa semakin baik struktur organisasi yang berjalan di dalam organisasi maka akan semakin baik pula efektivitas organisasi yang berjalan di BPS Kabupaten/Kota se-Nusa Tenggara Barat. Struktur organisasi yang ada saat ini menurut peraturan Kepala BPS No. 121 Tahun 2001, dirasa sudah sederhana dan dapat diterapkan dengan baik dalam menunjang efektivitas organisasi.

Dalam model regresi logistik yang dihasilkan, variabel struktur organisasi mempunyai nilai koefisien beta yang paling besar yaitu 2,654. Artinya adalah efektivitas organisasi di BPS Kabupaten/Kota se-Nusa Tenggara Barat lebih dominan dipengaruhi 
oleh variabel struktur organisasi. Sehingga bagi para pengambil kebijakan perlu memberikan respon yang lebih terhadap permasalahan yang dihadapi dalam varibel ini.

Menurut Meter dan Horn dalam Winarno (1997), struktur organisasi adalah suatu hubungan karakteristik-karakteristik, norma-norma dan pola-pola hubungan yang terjadi di dalam badan-badan eksekutif yang mempunyai hubungan baik potensial atau nyata dengan apa yang mereka miliki dalam menjalankan kebijaksanaan. Sehingga tata kelola hubungan yang baik dari seluruh elemen di dalam organisasi perlu ditingkatkan dalam upaya untuk mengejar dan berpacu menciptakan efektivitas organisasi demi kepuasan terhadap masyarakat.

Hasil dalam penelitian ini sesuai dengan penelitiannya Waworuntu (2016) dan Gammahendra (2014) dimana struktur organisasi mempunyai pengaruh yang positif dan signifikan terhadap efektivitas organisasi. Namun hasil penelitian ini bertentangan dengan hasil penelitian yang dilakukan oleh Zheng (2009) dalam arah hubungan, dimana dalam penelitian Zheng (2009) struktur organisasi mempunyai pengaruh yang negatif.

\subsubsection{Pengaruh Kemampuan SDM Terhadap Efektivitas Organisasi di BPS} Kabupaten/Kota se-Nusa Tenggara Barat

Hasil penelitian ini mengindikasikan bahwa semakin baik kemampuan SDM seorang pegawai maka akan semakin meningkatkan efektivitas organisasi dengan lebih baik di BPS Kabupaten/Kota se-Nusa Tenggara Barat. Mayoritas responden dalam penelitian ini telah mempunyai kemampuan SDM yang baik yaitu sebesar 64,8 persen. Angka ini menunjukkan bahwa dukungan kemampuan SDM terhadap terwujudnya efektivitas organisasi yang lebih baik di BPS Kabupaten/Kota se-Nusa Tenggara Barat sudah cukup besar.

Menurut Simamora (1995) manajemen sumber daya manusia adalah pemberdayaan, pengembangan, penilaian, pemberian balas jasa, dan pengelolaan individu anggota organisasi atau kelompok pekerja. Manajemen sumber daya manusia yang efektif mengharuskan manager menemukan cara terbaik dalam mengkaryakan orang-orang agar mencapai tujuan yang diinginkan dan meningkatkan kinerja organisasi. Mengingat kemampuan SDM ini berpengaruh positif dan signifikan terhadap efektivitas organisasi di BPS Kabupaten/Kota se-Nusa Tenggara Barat , maka para pengambil kebijakan harus lebih meningkatan kapabilitas pegawainya dengan pendidikan dan pelatihan yang lebih baik. Hal ini adalah sebagai upaya organisasi dalam meningkatkan efektivitas organisasinya.

Temuan hasil penelitian ini sejalan dengan penelitian yang dilakukan oleh Prasetyaningsih (2009) dan Rofai (2006) dimana kemampuan SDM berpengaruh positif dan signifikan terhadap efektivitas organisasi.

\subsubsection{Pengaruh Motivasi Terhadap Efektivitas Organisasi di BPS Kabupaten/Kota se- Nusa Tenggara Barat}

Hasil penelitian ini mengindikasikan bahwa semakin tinggi motivasi seorang pegawai maka akan semakin meningkatkan efektivitas organisasi dengan lebih baik di BPS Kabupaten/Kota se-Nusa Tenggara Barat. Mayoritas responden dalam penelitian ini telah mempunyai motivasi yang tinggi yaitu sebesar 64,8 persen. Angka ini menunjukkan bahwa dukungan motivasi pegawai terhadap terwujudnya efektivitas organisasi yang lebih baik di BPS Kabupaten/Kota se-Nusa Tenggara Barat sudah cukup besar.

Motivasi merupakan dorongan yang membuat karyawan melakukan sesuatu dengan cara dan untuk mencapai tujuan tertentu (Mangkuprawira, 2007). Secara umum, sebagian pegawai di BPS Kabupaten/Kota se-NTB mempunyai motivasi yang baik. Namun pegawai yang telah senior cenderung menurun tingkat motivasinya. Mengingat motivasi ini berpengaruh positif dan signifikan terhadap efektivitas organisasi di BPS 
Kabupaten/Kota se-Nusa Tenggara Barat, maka motivasi harus senantiasa dipupuk agar dapat menjadi kekuatan dalam mensinergikan sumber daya demi pencapaian efektivitas organisasi.

Temuan hasil penelitian ini sejalan dengan penelitian yang dilakukan oleh Salabi (2015) dan Rofai (2006) dimana motivasi berpengaruh positif dan signifikan terhadap efektivitas organisasi.

\subsubsection{Tingkat Kecenderungan Pengaruh Variabel Bebas Terhadap Efektivitas Organisasi di BPS Kabupaten/Kota se-Nusa Tenggara Barat}

Berdasarkan model regresi logistik yang didapatkan, semua variabel masuk ke dalam model kecuali variabel kepemimpinan tidak dimasukkan ke dalam model karena tidak berpengaruh secara signifikan. Setelah kita mengetahui variabel mana yang berpengaruh, maka dapat kita interpretasikan mengenai tingkat kecenderungan pengaruh dari variabel bebas yang masuk ke dalam model dengan menggunkan nilai odds ratio.

Berdasarkan hasil analisis data pada bagian sebelumnya, struktur organisasi yang baik akan dapat meningkatkan efektivitas organisasi dengan lebih baik lagi sebesar 14,22 kali lipat dibandingkan struktur organisasi yang buruk. Kemampuan SDM yang baik akan dapat meningkatkan efektivitas organisasi dengan lebih baik lagi sebesar 10,47 kali lipat dibandingkan kemampuan SDM yang buruk. Dan motivasi yang tinggi akan dapat meningkatkan efektivitas organisasi dengan lebih baik lagi sebesar 9,96 kali lipat dibandingkan motivasi yang rendah.

\section{Kesimpulan, Saran, dan Keterbatasan}

\subsection{Kesimpulan}

Berdasarkan uraian di atas dapat disimpulkan bahwa : (1) Kepemimpinan berpengaruh positif tetapi tidak signifikan terhadap Efektivitas Organisasi, (2) Struktur Organisasi berpengaruh positif dan signifikan terhadap Efektivitas Organisasi, (3) Kemampuan SDM berpengaruh positif dan signifikan terhadap Efektivitas Organisasi, (4) Motivasi berpengaruh positif dan signifikan terhadap Efektivitas Organisasi, dan (5) Struktur Organisasi yang baik, Kemampuan SDM yang baik, dan Motivasi yang tinggi mempunyai tingkat kecenderungan pengaruh terhadap baiknya Efektivitas Organisasi masing-masing sebesar 14,22, 10,47, dan 9,96 kali lipat dibandingkan sebaliknya.

\subsection{Saran dan Keterbatasan}

Adapun saran teoritis yang dapat diberikan adalah (1) struktur organisasi, kemampuan SDM, dan motivasi terbukti secara statistik berpengaruh positif dan signifikan terhadap efektivitas organisasi. Namun nilai Negalgarke R-Square dan Overall Classification plot masing-masing bernilai 0,767 dan 96,1 persen sehingga masih terdapat 0,233 atau 3,9 persen variabel yang belum terjelaskan di dalam model. Sehingga diperlukan kajian terhadap variabel lainnya yang kemungkinan masih tidak tercakup dalam penelitian ini. (2) diperlukan pengambilan sampel yang lebih luas apalagi dengan melakukan sensus. Sehingga intepretasi data yang dihasilkan dapat lebih maksimal dan akurat menggambarkan kondisi yang sebenarnya.

Secara praktis, saran yang dapat diberikan adalah (1) mayoritas responden menyatakan efektivitas organisasi di BPS Kabupaten/Kota se-NTB telah berjalan dengan baik, sehingga perlu dipertahankan dan ditingkatkan. Para pegawai harus termotivasi dan berlombalomba dalam menciptakan efektivitas organisasi demi kepuasan masyarakat. (2) Berdasarkan temuan pada variabel yang signifikan dalam model regresi logistik tersebut, diperlukan kebijakan pimpinan dalam meningkatkan kualitas maupun kuantitas dari variabel-variabel tersebut seperti peningkatan koordinasi antar seksi, pendelegasian pekerjaan sesuai kemampuan, peningkatan kualitas pendidikan dan pelatihan, dan 
pemberian penghargaan terhadap pegawai. (3) Bagi lembaga pendidikan dapat melakukan pengembangan dan penelitian lebih mendalam lagi terkait faktor-faktor yang mempengaruhi efektivitas organisasi.

\section{DAFTAR PUSTAKA}

Amuniansyah., A. M. \& Erwin, R. (2014), "Pengaruh Spesialiasi Tugas dan Gaya Kepemimpinan Terhadap Efektivitas Kerja Pegawai Pada Badan Kepegawaian Daerah Kabupaten Kutai Timur", eJournal Administrative Reform, II (1), 1061-1075.

Azwar, S. (2009), Penyusunan Skala Psikologi, Yogjakarta : Pustaka Pelajar.

Dessler, G. (2010), Manajemen Sumber Daya Manusia, (Jilid I), Jakarta: Prenhalindo.

Gibson, J.L. (1984), Organisasi dan Manajemen, Jakarta: Erlangga.

Gibson, J.L. (1994), Organisasi Struktur, Proses, Jakarta : Erlangga.

Gibson, J.L. (1996), Organisasi, Perilaku, Struktur, Proses, Jakarta: Bina Rupa Aksara.

Handoko, T. H. (2000), Manajemen Personalia dan Sumber Daya Manusia, Yogyakarta: BPFE.

Hosmer, D. W. \& Lemeshow, S. (2000), Applied Logistic Regression, New York: John Wiley and Sons, Inc.

Ivancevich. J.M. (2010), Perilaku Organisasi, Jakarta : Index.

Kutner, M.H., Nachtsheim, C.J., \& Neter, J. (2004), Applied Linear Regression Models, Singapore : The McGraw-Hill Companies.

Mangkuprawira, S., \& Hubies, A.V. (2007), Manajemen Mutu Sumber Daya Manusia, Bogor: Ghalia Indonesia.

Peters, T. J. W., Robert, H. (1982), In Search of Excellence: Lesson from America's Best Run Companies, New York: Harper \& Row, Pub.

Prasetyaningsih. (2009), Pengaruh Struktur Organisasi, Kepemimpinan dan Kemampuan SDM Terhadap Efektivitas Pelayanan Persertifitkatan Hak Atas Tanah Pada Kantor Pertanahan Kabupaten Kendal (Tesis, program Pascasarjana Universitas Diponegoro).

Rivai, V. (2004), Kepemimpinan dan Perilaku Organisasi, Jakarta: PT Raja Grafindo Persada.

Robbins, S.P. (2010), Perilaku Organisasi, Jakarta: Edisi Bahasa Indonesia, Prinhalindo.

Rofai, A. (2006), Analisis Faktor-Faktor Yang Mempengaruhi Efektivitas Organisasi Pada Badan Kesatuan Bangsa Dan Perlindungan Masyarakat Propinsi Jawa Tengah (Tesis, program Pascasarjana Universitas Diponegoro).

Siagian, S. P. (1982), Administrasi Pembangunan, Jakarta: Gunung Agung.

Simamora, H. (1995), Manajemen Sumber Daya Manusia, Jakarta: STIE YKPN. 
Steers, R. M. (1985), Efektivitas Organisasi, (Edisi Pertama), Jakarta: Erlangga

Sugiyono. (2009), Statistika Untuk Penelitian, Bandung : Alfabeta

Suradinata, E. (1995), Psikologi Kepegawaian dan Peranan Pimpinan Dalam Motivasi Kerja, Bandung: CV Ramadan.

Surbakti, A., \& Sri M., (2016), "Influence on Effective School Leadership in Primary Schools Deli Serdang In North Sumatera", International Journal of Education and Research, IV(1), 195-202.

Thahier, R., \& Nurhaslia., (2016), 'The Effects of Leadership on Organizational Effectiveness of Health Department in Wakatobi District South East Sulawesi, Indonesia', International Journal of Humanities and Cultural Studies, I(8), 313-325.

Waworuntu, C.T., Johnny H.P., \& Stefanus S., (2016), 'Influence Of Organizational Structure Of Effectiveness Of Birth Certificate Of Service In The Department Of Population And Notes Civil District Of South Minahasa', Jurnal Administrasi Publik, I(37), 1-8.

Winarno, V. (1997), Manajemen Kualitas, Jakarta: Gramedia.

Yukl, G. (1994), Kepemimpinan dalam Organisasi, Jakarta: Indeks.

Zheng, Wei.,Baiyin Y. \& Gary N.M., (2010), “Linking Organizational Culture, Structure, Strategy, and Organizational Effectiveness: Mediating Role of Knowledge Management", Journal of Business Research, XXXXIII(1), 763-771. 